\title{
Renal Transplantation in HIV-Infected Patients: The First Portuguese Review
}

\author{
S. Querido ${ }^{a, \star}$, D. Machado ${ }^{b}$, C. Silva ${ }^{c}$, F. Nolasco ${ }^{c}$, A. Nunes ${ }^{d}$, S. Sampaio ${ }^{d}$, P. Cruz ${ }^{e}$, C. Oliveira ${ }^{e}$, \\ and $A$. Weigert ${ }^{\mathrm{b}}$
}

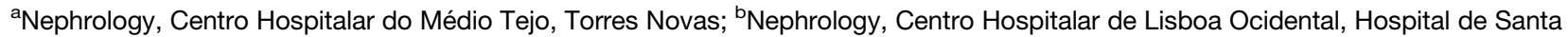
Cruz, Carnaxide; ' Nephrology, Centro Hospitalar de Lisboa Central, Hospital Curry Cabral, Lisboa; dephrology, Hospital de São João, Porto; and ${ }^{\mathrm{N}}$ Nephrology, Hospital Garcia de Orta, Almada, Portugal

\begin{abstract}
Introduction. With the introduction of combination antiretroviral therapy (cART), prognosis of human immunodeficiency virus (HIV) infection has been improved and kidney transplantation (KT) in HIV-positive patients became possible.

Methods. We reviewed the demographic, clinical, laboratory, and therapeutic data of all the HIV-infected patients who underwent KT between 2009 (first KT in Portugal in a HIVinfected patient) and May 2014. Case accrual was through all Portuguese KT centers where a KT in an HIV-infected patient was performed. Patients were transplanted following the American and Spanish guideline recommendations that included maintenance on cART, undetectable plasma HIV RNA copies, and absolute CD4 counts of $\geq 200$ cells $/ \mu \mathrm{L}$ in the last 6 months.

Results. Fourteen KT were performed on men and 3 on women. The mean age of patients at the time of transplantation was $49.9 \pm 11.7$ years. HIV status was known for $12 \pm 5$ years. Eight patients had AIDS in the past and all patients received grafts from deceased donors. Twelve patients $(64.7 \%)$ underwent induction therapy with basiliximab and 2 patients experienced early graft loss. In 2 patients, humoral rejection was diagnosed and in 3 patients, cellular rejection. Two patients died and an additional patient had early graft loss. Conclusion. KT is a possible, but challenging, renal replacement therapy in selected HIVpositive patients. Even in those with AIDS criteria in the past, when the disease is controlled, and after the reconstitution of the immune system with cART, KT can be performed. Nevertheless, the risk-benefit ratio for each patient needs to be taken in consideration.
\end{abstract}

$\mathbf{W}^{1}$ ITH THE INTRODUCTION of combination antiretroviral therapy (cART) in 1996, prognosis of human immunodeficiency virus (HIV) infection has improved owing to a sustained suppression of HIV replication and immunologic recovery and the risk of opportunistic infections became very low [1,2]. Therefore, kidney transplantation (KT) became possible in HIV-positive patients. In the United States and Europe, approximately $1 \%-1.5 \%$ of patients with end-stage renal disease (ESRD) are infected with HIV [3,4]. In January 2014, 151 HIV-positive patients were undergoing dialysis in Portugal and 9 of these patients were on a waiting list for KT [5].

Several scientific societies have developed guidelines regarding organ transplantation in these patients. The

$0041-1345 / 15$

http://dx.doi.org/10.1016/j.transproceed.2015.03.029 candidate for KT should not suffer from any condition included in category $\mathrm{C}$ that define AIDS, CD4 lymphocyte count should be $>200$ cells $/ \mu \mathrm{L}$, and HIV viral load should be undetectable [6,7] for a period of $\geq 6$ months. Social and psychiatric evaluations must be done and, usually, in drug abusers, a period of abstinence of $>2$ years is recommended.

Furthermore, although the frequency of AIDS defining events has decreased, non-AIDS-related events, including ESRD, has increased. HIV-infected patients may suffer

*Address correspondence to Sara Querido, Nephrology, Centro Hospitalar do Médio Tejo, Av. Xanana Gusmão - Apartado 45, 2350 - 754 - Torres Novas, Portugal. E-mail: saraqueridoconde@ gmail.com

(c) 2015 by Elsevier Inc. All rights reserved. 360 Park Avenue South, New York, NY 10010-1710 
Table 1. Demographic and Clinical Data From HIV-Positive Recipients

\begin{tabular}{|c|c|c|c|c|c|c|c|c|}
\hline Patient & Gender & Age & $\begin{array}{l}\text { HIV Diagnosis } \\
\text { (year) }\end{array}$ & Rejection & Coinfection & $\begin{array}{c}\text { Follow-up } \\
\text { After KT (mo) }\end{array}$ & $\begin{array}{c}\mathrm{CrCL} \text { MDRD }\left(\mathrm{mL} / \mathrm{min} / 1.73 \mathrm{~m}^{2}\right) \\
6 / 12 / 24 / 36 \mathrm{mo}\end{array}$ & Graft Loss/Patient Death \\
\hline 1 & M & 57 & 1998 & $\mathrm{AHR}$ & BK & 34 & $36 / 33 / 31 /-$ & No \\
\hline 2 & M & 51 & 2002 & No & No & 21 & 83/95/-/- & No \\
\hline 3 & M & 66 & 1999 & No & No & 14 & $53 / 49 /-1-$ & No \\
\hline 4 & M & 43 & 1987 & No & No & 16 & $54 / 60 /-1-$ & No \\
\hline 5 & M & 66 & 1998 & No & No & 3 & - & No \\
\hline 6 & $\mathrm{~F}$ & 35 & 1996 & No & No & 3 & - & No \\
\hline 7 & M & 38 & 1994 & No & $\mathrm{HCV}$ & 0 & - & Death/graft loss: hypovolemic shock \\
\hline 8 & M & 65 & 2003 & No & No & 0 & - & Graft loss: vascular thrombosis \\
\hline 9 & M & 32 & 2009 & No & No & 15 & $35 / 63 /-1-$ & No \\
\hline 10 & M & 65 & 2003 & AHR & No & 8 & $53 /-1-1-$ & No \\
\hline 11 & $\mathrm{~F}$ & 48 & 2005 & ACR & No & 6 & $76 /-/-/-$ & No \\
\hline 12 & M & 56 & 1999 & ACR & No & 3 & - & No \\
\hline 13 & M & 44 & 2005 & ACR & No & 52 & $75 / 43 / 58 / 49$ & No \\
\hline 14 & M & 45 & 2000 & No & No & 42 & $91 / 66 / 72 / 88$ & No \\
\hline 15 & $\mathrm{~F}$ & 58 & 2003 & No & No & 24 & $63 / 61 / 52$ & No \\
\hline 16 & $M$ & 47 & 2002 & No & No & 21 & 91/94/-/- & No \\
\hline 17 & M & 64 & 2006 & No & No & 2 & - & Death: H1N1 infection \\
\hline
\end{tabular}

Abbreviations: ACR, acute cellular rejection; AHR, acute humoral rejection; CrCL, creatinine clearance; F, female; HCV, hepatitis $\mathrm{C}$ virus; HIV, human immunodeficiency virus; M, male; mo, months; MDRD, Modification of Diet in Renal Disease.

from kidney failure owing to usual causes of ESRD or directly owing to HIV infection, including HIV-related nephropathy (HIVAN), immune complex-mediated glomerulonephritis, and thrombotic microangiopathy [8]. Additionally, HIV-infected patients may suffer kidney injury through complications of infection or nephrotoxicity of antiretroviral therapy [9].

In our study, we evaluated the characteristics and evolution of all patients who received a renal allograft in Portugal between 2009 and May 2014.

\section{METHODS}

We reviewed the charts of all HIV-infected patients who had undergone KT between 2009 (first KT in Portugal in a HIV-infected patient) and May 2014. We analyzed HIV subtype, evolution of the viral disease, etiology of the renal disease, diabetes, time on dialysis, immunologic compatibility, coinfection with cytomegalovirus and $\mathrm{BK}$, immunosuppression and antiretroviral therapies before and after KT, rejection episodes, graft function, and graft and patient survival. Renal function was expressed as estimated glomerular filtration rate (eGFR) using the Chronic Kidney Disease Epidemiology Collaboration equation.

\section{Statistics}

Statistical parameters were calculated using Microsoft Office Excel 2011 and were used the following parameters: percentage, average, or standard deviation.

\section{RESULTS}

We identified $17 \mathrm{KT}$ in 16 different patients (1 re-KT). Six KT were performed in Hospital de Santa Cruz, 6 KT (in 5 patients) in Hospital Curry Cabral, 4 KT in Hospital de São João, and $1 \mathrm{KT}$ in Hospital Garcia de Orta, which was the first performed in Portugal, in November 2009.
Of $17 \mathrm{KT}, 14$ were performed in men. The mean age of patients at the time of transplantation was $49.9 \pm 11.7$ years; 10 patients were Caucasian and $14 \mathrm{KT}$ were performed on HIV type 1 patients; 2 patients were HIV type 2 positive [10]. HIV status was known for $12 \pm 5$ years; the HCV co infection rate was $11.8 \%(2 / 17)$. Four patients had HIVAN, 2 patients had autosomal-dominant polycystic kidney disease. The other 3 had immunoglobulin (Ig)A nephropathy, diabetic nephropathy, and chronic glomerulonephritis. The etiology was uncertain in 8 patients whom had only known their kidney disease already in stage 5, precluding a histologic diagnosis. The median time on dialysis was $115.8 \pm 65.7$ months; 8 patients had previously fulfilled diagnostic criteria for AIDS in the past. However, AIDS criteria were not present for the 6 months before KT. Only 1 patient was not taking cART therapy before KT, but he started antiretroviral treatment after receiving the allograft. Five patients were under antiretroviral protocols that included ritonavirboosted protease inhibitors. Undetectable viral load and a CD4 lymphocyte count of $\geq 200$ cells $/ \mu \mathrm{L}$ were obtained in all recipients. All patients received grafts from deceased donors. All recipients and all donors had anti-cytomegalovirus IgG antibodies; 14 patients had $>3$ HLA mismatches with the donor and in 2 patients anti-HLA class I and II antibodies were identified. Six patients had a panel reactive antibody of $>25 \%$. Twelve patients $(64.7 \%)$ received induction therapy with basiliximab, 3 patients with polyclonal antibodies and 1 patients received rituximab and intravenous immunoglobulin (IVIg). Fifteen patients received triple maintenance immunosuppressive therapy consisting of tacrolimus, mycophenolate mofetil, and a corticosteroid. Two patients had an early graft loss, one owing to hypovolemic shock at the day 4 after KT, the other owing to vascular thrombosis at day 4 after KT. Two patients died, one owing to hypovolemic shock at day 4 after KT, and other at 2 months after KT, with a 
functioning graft, owing to H1N1 infection. One patient has been coinfected with polyomavirus BK 4 months after KT and his immunosuppressive regimen was changed to sirolimus, tacrolimus, and prednisone.

All recipients under antiretroviral therapy were maintained on previous cART; the patient who had never been under antiretroviral therapy before KT started cART after the procedure. All 5 patients who were under ritonavirboosted protease inhibitors remained on this drug regimen. However, it was necessary to reduce substantially the dose of tacrolimus to achieve therapeutic range.

Humoral rejection was detected in 2 patients and cellular rejection in 3 . The 3 patients with acute cellular rejection were treated with steroid pulses, with recovery of previous renal function. The 2 patients with acute humoral rejection were treated, 1 with plasmapheresis, rituximab, and IVIg, and the other with thymoglobulin, plasmapheresis, and IVIg. The first developed an acute humoral rejection episode after a significant reduction in the immunosuppression, in the context of coinfection with polyomavirus $\mathrm{BK}$. Both cases of humoral rejection recovered the previous eGFR. At the date of last follow-up, average time after KT was $17 \pm 14$ months. The last eGFR were $64.58 \pm 22.34 \mathrm{~mL} /$ $\min / 1.73 \mathrm{~m}^{2}$. We summarize the results in Table 1 .

\section{DISCUSSION}

Given the increased life expectancy since the introduction of cART, HIV-positive patients develop long-term complications, such as ESRD. In the United States and Europe, $1 \%-1.5 \%$ of patients with ESRD are infected with HIV $[3,4]$ and most of them are on dialysis owing to HIVAN. HIVAN is considered less common in Europe than in the United States. In our series, 4 patients $(23.5 \%)$ had HIVAN diagnosed as the cause of their ESRD. We cannot exclude that HIVAN could be the cause of the ESRD of the patients whose etiology was undetermined.

The prevalence of $\mathrm{HCV}$ infection in HIV-infected populations is high [11]. Coinfection with $\mathrm{HCV}$ was been described as a negative graft survival factor, possibly owing to longer times on dialysis and duration of HIV infection. Although the evolution of HCV may be more aggressive in HIV-positive patients, KT in patients simultaneously positive for $\mathrm{HCV}$ and HIV infection has shown better results than dialysis [12,13]. In our case, the HCV coinfection rate was $11.8 \%$, lower than the prevalence shown in some published literature [12].

Induction and maintenance therapy in HIV positive patients varies in different series [12-16] and raises some challenging questions. Several antiretrovirals are metabolized through cytochrome P450 (CYP450) and they may affect the function of this hepatic enzyme and P-glycoprotein (PGP) in the bowel. Ritonavir is used to boost protease inhibitors and is a potent CYP450 and PGP inhibitor. Calcineurin inhibitors and mammalian target of rapamycin inhibitors are metabolized in the liver through the CYP450 enzymatic system. Thus, the interactions between the 2 drugs lead to extremely high immunosuppressant levels. The use of integrase inhibitor-based regimens, such as raltegravir, may be useful to avoid those interactions.

The majority of our patients $(94.1 \%)$ received induction therapy, $70.5 \%$ of them with basiliximab and $29.5 \%$ with thymoglobulin. In the United States, $83 \%$ of patients received induction therapy, $51 \%$ of them with anti-CD25 [15]. In a French series, $100 \%$ of patients received induction therapy [16]. All patients of our series received triple maintenance immunosuppressive therapy, which included tacrolimus. The 5 patients who were receiving ritonavir-boosted protease inhibitors, maintained this drug, however, with the need to drastically reduce the dose of tacrolimus.

We report a rate of AR of $29.4 \%$, slightly lower than that reported in the literature $[12,13,15,16]$. The European and US studies describe a 1-year graft survival between $90.4 \%$ and $98 \%$ $[12,15,16]$. We had 2 cases of early graft loss, with a 1 -year graft survival of $88.25 \%$, equal to the patient survival. In our series, follow-up was $17 \pm 14$ months, which is insufficient to accurately estimate graft survival. These data reflect the Portuguese experience and are consistent with the literature results.

In conclusion, as in other series, KT seems to be an acceptable alternative to dialysis in selected HIV-positive patients, even in those with AIDS criteria in the past; however, high rejection rates can be expected. When the disease is controlled, and after the reconstitution of the immune system with cART, KT should be considered according to the risk-benefit ratio for each patient.

\section{REFERENCES}

[1] Podlekareva D, Mocroft A, Dragsted UB, et al. Factors associated with the development of opportunistic infections in HIV1-infected adults with high CD4+ cell counts: e EuroSIDA study. J Infect Dis 2006;194:633-41.

[2] vanSighem AI, Gras LA, Reiss P, et al. Life expectancy of recently diagnosed asymptomatic HIV-infected patients approaches that of uninfected individuals. AIDS 2010;24:1527-35.

[3] Barril G, Trullás JC, Gonzalez-Parra E, et al. Prevalence of HIV-1-infection in dialisys units in Spain and potential candidates for renal transplantation: results of a Spanish survey. Enferm Infecc Microbiol Clin 2005;23(6):335-9.

[4] Ahuja TS, Grady J, Khan S. Changing trends in the survival of dialyses patients with human immunodeficiency virus in the United Sates. J Am Soc Nephrol 2002;13(7):1889-93.

[5] Sociedade Portuguesa de transplantacao. Registo Nacional de Tranplatacao. Available from: www.sptregisto.com/renal/LoginAction. do? accio=inici.

[6] Steinman T, Becker BN, Frost A, et al. Guidelines for the referral and management of patients eligible for solid organ transplantation. Transplantation 2001;71(9):1189-204.

[7] Miro JM, Torre-Cisneros J, Moreno A, et al. Consensus document from GESIDA/GESITRA-SEIMC, SPNS and ONT on solid organ transplantation in patients with HIV infection in Spain. Enferm Infecc Microbil Clin 2005;23(6):353-62.

[8] Szczech LA, Gupta SK, Habash R, et al. The clinical epidemiology and course of the spectrum of renal diseases associated with the HIV infection. Kidney Int 2004;18:541-6.

[9] Post FA, Campbell LJ, Hamzah L, et al. Predictors of renal outcome in HIV-associated nephropathy. Clin Infect Dis 2008;46: $1282-9$.

[10] Natario A, Rodrigues B, Matias P, et al. Renal transplantation in a HIV-2 positive recipient in Portugal. Port J Nephrol Hypertens 2012;26:175-8. 
[11] Roland ME, Stock PG. Review of solid-organ transplantation in HIV-infected patients. Transplantation 2003;75:425-9.

[12] Mazuecos A, Fernández A, Andres A, et al. HIV infection and renal transplantation. Nephrol Dial Transplant 2011;26(4): 1401-7.

[13] Mazuecos A, Rodriguez Benot A, Moreno A, et al. Renal replacement therapy in patients with HIV infection in a European region: outcomes following renal transplantation. Transplant Proc 2012;44(7):2053-6.
[14] Gathogo E, Jose S, Jones R, et al. End-stage kidney disease and kidney transplantation in HIV-positive patients. An observational cohort study. J Acquir Immune Defic Syndr 2014;67(2):177-80.

[15] Stock PG, Barin B, Murphy B, et al. Outcomes of kidney transplantation in HIV-Infected recipients. N Engl J Med 2010;363(21):2004-14.

[16] Touzot M, Pillebout E, Matignon M, et al. Renal transplantation in HIV-infected patients: the Paris experience. Am J Transplant 2012;10(10):2263-9. 